\title{
Rediscovery and redescription of the rare, critically endangered snake Emmochliophis miops (Serpentes: Colubridae), with comments on its natural history, distribution, and phylogenetic relationships
}

\author{
Luis Enrique Vera-Pérez, ${ }^{1}$ Patrick D. Campbell, ${ }^{2}$ and Giovanna Gondim Montingelli ${ }^{3}$ \\ ${ }^{1}$ Independent researcher, carrera 8 \# 2A-12, Las Quintas, La Plata, Huila, Colombia. E-mail: dipsadini@gmail.com. \\ ${ }^{2}$ Department of Life Sciences, Natural History Museum. Cromwell Road, South Kensington, London SW7 5BD, United \\ Kingdom. E-mail: p.campbell@nhm.ac.uk. \\ ${ }^{3}$ Museu de Zoologia da Universidade de São Paulo. Avenida Nazaré, 481, 04263-000, Ipiranga, São Paulo, SP, Brazil. \\ E-mail: mastigodryas@gmail.com.
}

\begin{abstract}
Rediscovery and redescription of the rare, critically endangered snake Emmochliophis miops (Serpentes: Colubridae), with comments on its natural history, distribution, and phylogenetic relationships. The description of Emmochliophis miops is based on a single specimen from the Andean slopes of northwest Ecuador collected in 1897. The species had not been collected again until October 2017, when two individuals were found on the western slopes of the Cordillera Occidental of Colombia; this rediscovery is the first record of this species in this country. Herein, the holotype and the new specimens are examined, and a new diagnosis and description of E. miops are provided. Important data about the natural history and conservation status of the species, and comments on the systematic relationships of Diaphorolepis, Emmochliophis and Synophis are presented.
\end{abstract}

Keywords: Andean Shadow Snakes, Colombia, Diaphorolepidini, Ecuador, hemipenes, Parque Nacional Natural Munchique.

\footnotetext{
Resumen

Redescubrimiento y redescripción de la serpiente rara y en peligro crítico Emmochliophis miops (Serpentes: Colubridae), con comentarios sobre su historia natural, distribución y relaciones filogenéticas. La descripción de Emmochliophis miops está basada en un solo espécimen de las laderas andinas del noroeste de Ecuador recolectado en 1897. La especie no se volvió a recolectar hasta octubre de 2017, cuando dos individuos fueron encontrados en la vertiente occidental de la Cordillera Occidental de Colombia; este redescubrimiento es el primer registro de esta especie en
}

Received 17 June 2019

Accepted 05 February 2020

Distributed June 2020 
este país. En este estudio, el holotipo y los nuevos especímenes son examinados y se proporciona un nuevo diagnóstico y descripción de E. miops. Se presentan datos importantes sobre la historia natural y el estado de conservación de la especie, y comentarios sobre las relaciones sistemáticas de Diaphorolepis, Emmochliophis y Synophis.

Palabras claves: Colombia, Culebras Andinas de la Sombra, Diaphorolepidini, Ecuador, hemipenes, Parque Nacional Natural Munchique.

\begin{abstract}
Resumo
Redescoberta e redescrição da rara e criticamente ameaçada serpente Emmochliophis miops (Serpentes: Colubridae), com comentários sobre história natural, distribuição e relações filogentéticas. A descrição de Emmochliophis miops baseia-se em apenas um espécime procedente das vertentes Andinas do noroeste do Equador, coletado em 1897. Representantes dessa espécie não haviam sido coletados até outubro de 2017 , quando dois indivíduos foram encontrados na Cordilheira Ocidental da Colômbia; esta redescoberta consiste no primeiro registro dessa espécie no país. Neste estudo, examinamos o holótipo e os novos espécimes e propomos uma nova diagnose e descrição de E. miops. Apresentados dados importantes sobre a história natural e o estado de conservação da espécie, além de comentários sobre as relações sistemáticas de Diaphorolepis, Emmochliophis e Synophis.
\end{abstract}

Palavras-chave: cobras-andinas-das-sombras, Colômbia, Diaphorolepidini, Equador, hemipênis, Parque Nacional Natural Munchique.

\section{Introduction}

The colubrid tribe Diaphorolepidini currently is composed of Diaphorolepis (2 spp.), Emmochliophis (2 spp.), and Synophis (9 spp.); it is diagnosed by the presence of fused prefrontals, and either an expanded intervertebral scale row or expanded zygapophyses and neural spines in adults (Pyron et al. 2016). Members of the tribe are distributed from Darien, Panama, to the northern Andes in Colombia, Ecuador, and Peru (Bogert 1964, Hillis 1990, Sheil 1998, Sheil and Grant 2001, Pyron et al. 2015, 2016, TorresCarvajal et al. 2015).

Recently a number of specimens of Diaphorolepis wagneri Jan, 1863 and Synophis have been collected; however, other species in Diaphorolepidini remain rare and enigmatic (Hillis 1990, Arteaga et al. 2013, Pyron et al. 2015, 2016, Torres-Carvajal et al. 2015). Synophis plectovertebralis Sheil and Grant, 2001, Diaphorolepis laevis Werner, 1923, Emmochliophis fugleri Fritts and Smith, 1969, and E. miops (Boulenger, 1898) are known only by their type specimens.

Emmochliophis is composed of relatively small-sized terrestrial snakes restricted to the Pacific Andean slopes of northwestern Ecuador. They are easily differentiated from the other two genera of Diaphorolepidini by the absence of a loreal scale and no reduction in the number of scale rows from neck to vent ( $v s$. loreal present and reduced scale rows from anterior to posterior body in Synophis and Diaphorolepis) (Fritts and Smith 1969, Sheil 1998, Pyron et al. 2015, 2016). Emmochliophis miops is only known from a single specimen collected in 1897 (Boulenger 1898), and is listed on the IUCN Red List as Critically Endangered, under criterion $\mathrm{B} 1 \mathrm{ab}(\mathrm{iii})$ that refers to a distribution area of $<100 \mathrm{~km}^{2}$, a single locality, and a continued decline in range and/or habitat quality (Cisneros-Heredia and Yánez-Muñoz 2017). According to these authors, no suitable habitat remains at the type locality owing to complete deforestation for timber extraction 
and then cattle ranching; in addition, nearby forests have been replaced with palm oil plantations. It is thought that E. miops may be sensitive to changes in humidity that would not allow it to persist in disturbed forests.

In late 2015, LEV-P observed some photographs of snakes found in La Cueva sector of the Parque Nacional Natural Munchique, Colombia, taken by a colleague. Some of the photos were of a slender, black snake with a white nuchal collar that was identified as Ninia atrata (Hallowell, 1845) and not collected. However, on close examination, photographs showed that fused prefrontals were present; thus, it is not $N$. atrata, and the presence of a single keeled intervertebral scale row indicates that it is not in Diaphorolepis. The snake could be a Synophis, but the presence of a loreal scale could not be confirmed. The possible absence of the loreal scale led to the possibility that the snake was a species of Emmochliophis. A more thorough search was carried out at La Cueva in November 2016, but the species was not encountered. On 17 October 2017 at La Cueva, LEV-P captured a snake that resembled the specimen photographed, and on the following night a second individual was found. Neither snake has a loreal scale, thereby confirming their identification as Emmochliophis miops; this is the first record of this species in the wild in the 120 years since the collection and description of the holotype.

We compare the new specimens with the holotype, and redescribe the species, providing information on its natural history, conservation status, and some comments on the tribe Diaphorolepini.

\section{Materials and Methods}

We examined the holotype of Emmochliophis miops (BMNH 1946.1.12.30) housed in the Natural History Museum, London (NHMUK), along with the two new specimens and a specimen of Diaphorolepis cf. wagneri that are deposited at Museo de Historia Natural of the Universidad del Cauca, Colombia (MHNUC). Specimens were collected in the La Cueva sector of the Parque Nacional Natural Munchique in the municipality of El Tambo, department of Cauca, Colombia (02 $46^{\circ} 18.1^{\prime \prime} \mathrm{N}, 76^{\circ} 58^{\prime} 51.5^{\prime \prime} \mathrm{W}, 1040$ $\mathrm{m}$ a.s.1.) under agreements TW25 of 2016 and TW63 of 2017 "Conservación de la biodiversidad en paisajes impactados por la minería en la región del Chocó Biogeográfico", issued by World Wildlife Foundation and Fundación Ecohábitats as part of monitoring program of the PNN Munchique.

Species identification is based on the taxonomic key of Pyron et al. (2016). The following morphometric characters and measurements were recorded: SL $=$ supralabials, $\mathrm{IL}=$ infralabials, $\mathrm{PrO}=$ preoculars, $\mathrm{PO}$ $=$ postoculars, Temp $=$ temporals, $\mathrm{PV}=$ preventrals, $\mathrm{V}=$ ventrals, $\mathrm{SC}=$ subcaudals, $\mathrm{DSR}=$ dorsal scale rows, $\mathrm{MT}=$ maxillary teeth, $\mathrm{SVL}=$ snout-vent length, $\mathrm{TL}=$ tail length. $\mathrm{Sex}$ was determined by the presence or absence of hemipenes. Ventral scale counts follow those of Dowling (1951); subcaudal scales were counted in pairs, excluding the terminal spine. Total and tail lengths were measured with a ruler to the nearest $1.0 \mathrm{~mm}$; cephalic and hemipenial measurements were taken with dial calipers to the nearest $0.1 \mathrm{~mm}$ under a stereo microscope. Maxillary teeth were counted on both sides through a narrow incision between the supralabials and the maxillary arch with the aid of a stereo microscope.

Hemipenes were prepared following the methods of Myers and Cadle (2003) and Zaher and Prudente (2003); both were almost maximally expanded by injections of colored petroleum jelly and stained with Alizarin Red S to elucidate the calcareous spines (Uzzell 1973). Hemipenial terminology follows that of Dowling and Savage (1960), as augmented by Zaher (1999). For comparisons, hemipenial morphology of Synophis were taken from Zaher (1999), Sánchez-Martínez (2011) and Torres-Carvajal et al. (2015). 


\section{Results}

\section{Emmochliophis miops (Boulenger, 1898) (Figures 1-6) \\ Synophis miops Boulenger, 1898}

Holotype.-An adult female (BMNH 1946.1.12.30) collected by W. F. H. Rosenberg in October 1897 from Paramba, Ecuador (= Parambas, Imbabura fide Lynch and Duellman 1997).

New specimens.-A juvenile female (MHNUC-HE-Se-0657) and an adult male (MHNUC-HE-Se-0658), both collected by LEV-P in the La Cueva sector of the Parque Nacional Natural Munchique, municipality of El Tambo, department of Cauca, Colombia (02 46'13.1" N, 76 58'47.7" W, 1142 m a.s.l.; $02^{\circ} 46^{\prime} 13.6^{\prime \prime} \mathrm{N}, 76^{\circ} 58^{\prime} 44.5^{\prime \prime} \mathrm{W}, 1188 \mathrm{~m}$ a.s.l.; respectively).

Diagnosis.-(1 male and 2 females): Emmochliophis miops is distinguished from E. fugleri and other species of Diaphorolepidini by the following combination of characters: (1) intervertebral scale row single keeled; (2) dorsal scales keeled, in 19|19|19 rows; (3) prefrontals fused, in contact with supralabials; (4) loreal absent; (5) preoculars 1 or 2 ; (6) postoculars 1 or 2 ; (7) temporals $1+2 ;(8)$ supralabials $8,4^{\text {th }}$ and $5^{\text {th }}$ in contact with orbit; (9) infralabials 8 , first four in contact with first pair of chinshields; (10) ventrals 141 in male, 137 in females; (11) subcaudals more than 62 in males, 90 and 94 in females; (12) maxillary teeth 13-15; (13) dorsum dark gray with white nuchal collar after few months of preservation, and brown with a cream nuchal collar in holotype (Figures 1-2); (14) venter grayish after preservation, and cream in holotype; (15) chin tubercles present in males and juvenile females but absent in adult females (Figure 3); (16) hemipenis bilobed, semicalyculate, and semicapitate with a lateral naked pocket at base of organ (Figure 4).

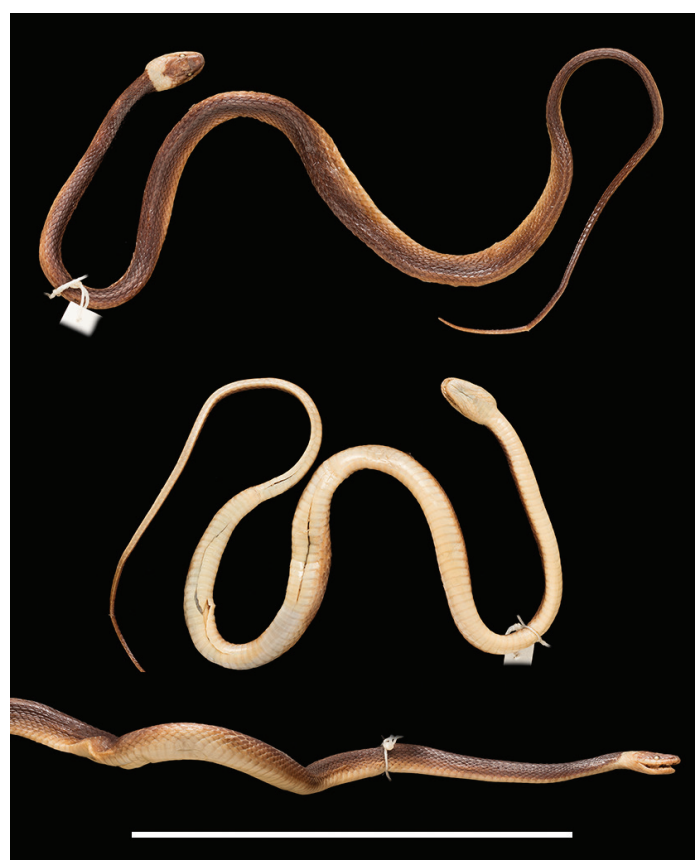

Figure 1. Dorsal (upper), ventral (middle) and lateral (lower) views of the holotype $\mathrm{BMNH}$ 1946.1.12.30 of Emmochliophis miops. Scale bar $=100$ mm. Photographs @The Trustees of the Natural History Museum, London.

Comparisons.-Diaphorolepidini includes slender snakes that are dark dorsolaterally, and have keeled scales, fused prefrontals and a long head. Emmochliophis miops differs from Diaphorolepis (characters in parentheses) by having an intervertebral scale row of single keeled and not expanded (double keeled and expanded), dorsal scale rows with no reduction (reduced posteriorly), loreal absent (present), infralabials 8 (10-13), maxillary teeth 13-15 (16-25), ventral scales $\leq 141$ (157-197), and nuchal collar complete in juveniles and adults (incomplete and present only in juveniles). Species of Synophis also have a loreal scale, reduction in dorsal scale rows, nuchal collar absent (except in S. plectovertebralis), more maxillary teeth (16-27), more infralabials up to a maximum of 12 (except in $S$. calamitus Hillis, 1990, S. plectovertebralis, and S. zaheri Pyron, 


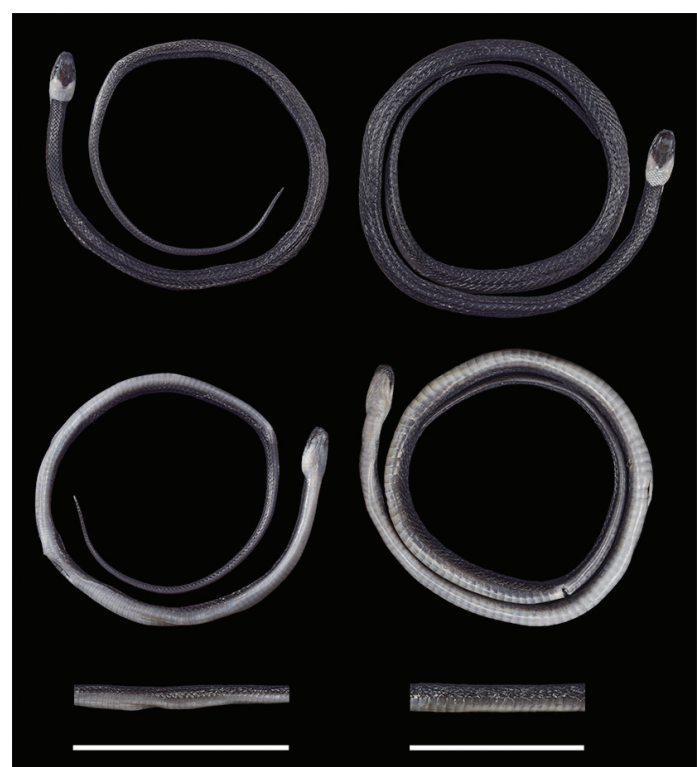

Figure 2. Dorsal (upper), ventral (middle) and lateral (lower) views of new specimens of Emmochliophis miops: MHNUC-HE-Se-0657 (left), MHNUC-HE-Se-0658 (right). Scale bars $=40 \mathrm{~mm}$. Photographs by LEV-P.

Guayasamin, Peñafiel, Bustamante and Arteaga, 2015, which can also have 7 or 8 ), and more ventral scales (144-193).

The differences between Emmochliophis miops and E. fugleri include the latter having no nuchal collar, 16 maxillary teeth, and unique interlocking trunk vertebrae. Juveniles of Geophis nigroalbus Boulenger, 1908 and some individuals of Ninia atrata and $N$. teresitae Angarita-Sierra and Lynch, 2017 can be confused with E. miops by having keeled scales and a dorsolateral black coloration with a light whitish nuchal collar. However, these three species can be easily differentiated by the absence of fused prefrontals.

Description.-Based on the holotype, an adult female, and a juvenile female and adult male. Slender and relatively small-sized snakes ( $\leq 258 \mathrm{~mm} \mathrm{SVL}$ ) (Table 1); head length $2 \times$

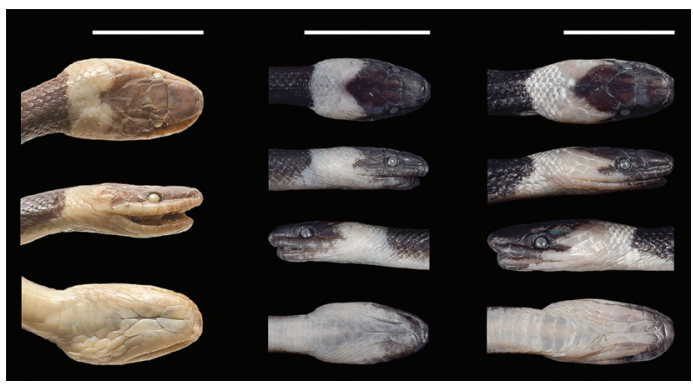

Figure 3. Head of Emmochliophis miops in dorsal (upper), lateral (middle) and ventral (lower) views. Holotype BMNH 1946.1.12.30 (left), MHNUC-HE-Se-0657 (center), MHNUC-HESe-0658 (right). Scale bars $=10 \mathrm{~mm}$. Photographs courtesy of @The Trustees of the Natural History Museum, London and LEV-P.

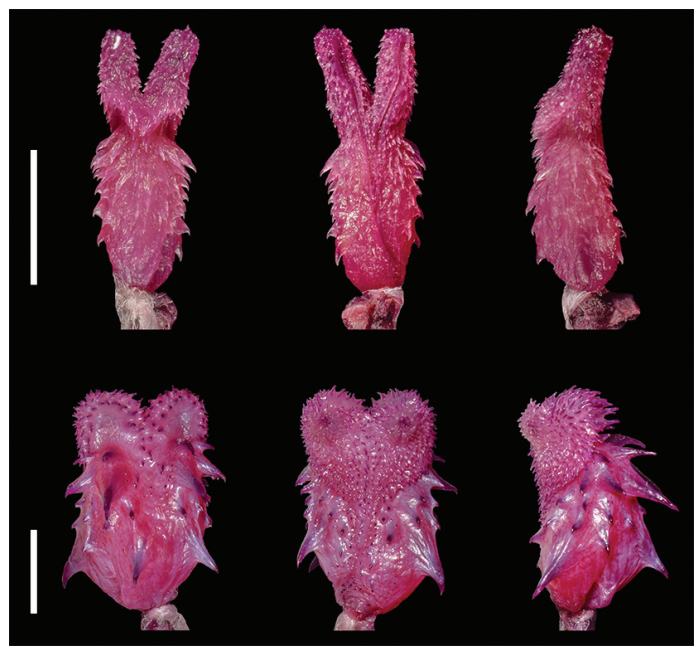

Figure 4. Hemipenis of Emmochliophis miops (upper, right organ of MHNUC-HE-Se-0658) and Diaphorolepis cf. wagneri (lower, left organ of MHNUC-HE-Se-0650) in asulcate (left), sulcate (center) and lateral (right) views. Scale bars $=5 \mathrm{~mm}$. Photographs by LEV-P.

width, easily differentiated from neck, flattened laterally; snout truncate in dorsal and ventral views, rounded in lateral view; eye small; dark gray dorsolaterally after 3 months in preservative; 
nuchal collar V-shaped, white, covering temporals, part of parietals, postoculars, last supralabials and infralabials, gulars, chin shields, preventrals and first ventrals; snout black; venter pale gray anteriorly, darker posteriorly; rostral scale slightly visible from above; internasals in contact; fused prefrontals, in contact with supralabials; loreal absent; preoculars 1 or 2, with the second represented by a small subpreocular (left side of MHNUC-HESe-0657); supraocular 1; postoculars 1 or 2, with the second represented by a small subpostocular (right side of MHNUC-HE-Se-0657); temporals $1+2$, primary $2 \times$ secondary in length; supralabials 8 , with $4^{\text {th }}$ and $5^{\text {th }}$ bordering the orbit; infralabials $8,1^{\text {st }}-4^{\text {th }}$ contacting anterior chin shields; dorsal scales in 19 rows with no reduction, dorsolateral rows single keeled; apical pits absent; anal plate entire; preventrals 1 or 2; ventrals 137-141, subcaudals 90 and 94 (MHNUC-HE-Se-0658 with a broken tail); chin tubercles present on first infralabials and on anterior chin shields in juvenile females (weak) and males (strongly expressed in adults). Maxillary teeth 13-15, equal in number on each side.

Hemipenial morphology.-Hemipenis bilobed, semicalyculate, and semicapitate (Figure 4, upper); $9.8 \mathrm{~mm}$ total in length; capitulum and body relatively similar in length (4.4 and $5.4 \mathrm{~mm}$, respectively); lobes spinulate, with spines slightly larger and numerous on asulcate surface where the capitular groove forms; few spinules on the asulcate side of the lobes; sulcus spermaticus centrolineal, bifurcating at mid-portion of body and terminating at the apex; body ornamented by calcified spines, larger basally and shorter on lateral surfaces near the sulcus spermaticus; nude pocket present at the base of the organ (right side, on asulcate side).

Color in life.-Dorsolateral color of Emmochliophis miops black, interrupted only by the

Table 1. Summary of morphological characters and measurements ( $\mathrm{mm}$ ) of Emmochliophis miops. See Materials and Methods for abbreviations. Solidus separates the right/left sides when counts are different. Numbers in parentheses correspond to scales bordering the orbit and contacting the first pair of chin shields. Dashes separate the anterior, mid-body and posterior DSR counts. Asterisk indicates an incomplete tail.

\begin{tabular}{lccc}
\hline Characters & BMNH 1946.1.12.30 & MHNUC-HE-Se-0657 & MHNUC-HE-Se-0658 \\
\hline Sex & Female & Female & Male \\
SVL & 255 & 142 & 258 \\
TL & 135 & 68 & $91^{*}$ \\
SL & $8(4,5)$ & $8(4,5)$ & $8(4,5)$ \\
IL & $8(1-4)$ & $8(1-4)$ & $8(1-4)$ \\
PrO & 1 & $1 / 2$ & 1 \\
PO & 1 & $2 / 1$ & 1 \\
Temp & $1+2$ & $1+2$ & $1+2$ \\
PV & 2 & 1 & 2 \\
V & 137 & 137 & 141 \\
SC & 94 & 90 & $62^{*}$ \\
DSR & $19-19-19$ & $19-19-19$ & $19-19-19$ \\
MT & 13 & 14 & 15 \\
\hline
\end{tabular}


white nuchal collar, which in juveniles is narrower and creamy (Figure 5). Venter light to medium gray, interrupted only by the white nuchal collar and the black snout. Ventral surface of tail dark gray.

Distribution.-Western slopes of the Andes in Parambas, province of Imbabura (fide Lynch and Duellman 1997) in northern Ecuador (type locality), and western slopes of the Cordillera Occidental in the La Cueva sector of the Parque Nacional Natural Munchique, municipality of El Tambo, department of Cauca, Colombia (Figure 6). Elevation of type locality as provided by Boulenger (1898) $1066.8 \mathrm{~m}$ a.s.l., or 777 and $780 \mathrm{~m}$ a.s.l. as corrected by Brown (1941) and Lynch and Duellman (1997), respectively. Colombian specimens were captured at 1142 and $1188 \mathrm{~m}$ a.s.l.
Natural history.-The species occurs in the transition from humid premontane to tropical humid forests. It is a nocturnal terrestrial snake that moves slowly on the forest floor and among

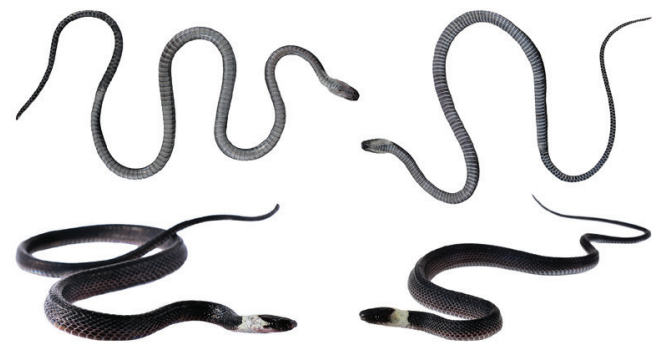

Figure 5. Coloration in life of Emmochliophis miops in ventral (upper) and dorsolateral (lower). Adult male (left, MHNUC-HE-Se-0658) and juvenile female (right, MHNUC-HE-Se-0657). Photographs by LEV-P.



Figure 6. Geographical distribution of Emmochliophis miops. The star corresponds to the type locality in Parambas, province of Imbabura, Ecuador and the circle corresponds to the new locality record in La Cueva sector, Parque Nacional Natural Munchique, municipality of El Tambo, department of Cauca, Colombia. 
rock piles. The only information on its diet is provided by Sheil (1998), from the holotype, and consists of an unidentified lizard. No stomach contents were found in the two specimens collected in this study. No defensive behaviors, such as bites, sudden movements, expulsion of excrement or secretions of the anal glands were noted upon capture. This species is delicate and highly sensitive to changes in humidity and temperature. When recently captured animals were handled, we observed that the dorsal scales became wrinkled to form a longitudinal crest, and the skin between lateral scales expanded. Minutes later, the individuals stiffened, especially along the tail, and gradually became motionless as the head flattened.

Conservation status._-Emmochliophis miops should remain as Critically Endangered, but we consider a change on criterion from B1ab(iii) (Cisneros-Heredia and Yánez-Muñoz 2017) to A1ac (IUCN 2012) because, although the species occurs within a protected area in Colombia, it has not been found in Ecuador since the holotype was collected in 1897, suggesting that it may have been extirpated in the course of degradation and loss of habitat.

\section{Discussion}

The genus Emmochliophis was erected by Fritts and Smith (1969) and diagnosed by its unique interlocking trunk-vertebral mechanism, a condition present only in the type species $E$. fugleri. When Sheil (1998) included Synophis miops in Emmochliophis, he designated this character as autapomorphic of E. fugleri, and considered the absence of fused lateral projections of prezygapophyses and postzygapophyses of trunk vertebrae as a synapomorphy for Emmochliophis, a condition has not yet been evaluated in most of the Synophis group. In their description of $S$. plectovertebralis, Sheil and Grant (2001) reported that the only reliable characters differentiating Emmochliophis from Synophis are the non-reduction of scale rows and the absence of the loreal scale.
We suggest that the presence of a lateral naked pocket on the base of the hemipenis of Emmochliophis miops is a significant character that should be evaluated in a detailed review of the hemipenis of the holotype of E. fugleri. We need to determine whether the hemipenial pocket is an autapomorphy of E. miops or a synapomorphy for the genus because this character seems to be absent in Synophis. A review of the morphology of trunk vertebrae in the species of Synophis is needed to evaluate Sheil's (1998) proposed synapomorphy for Emmochliophis, because fusion of the lateral projections of prezygapophyses and postzygapophyses is also present in $S$. plectovertebralis (Sheil and Grant 2001).

Species of Diaphorolepidini have been thought to have a similar hemipenial morphology (Bogert 1964, Fritts and Smith 1969, Pyron et al. 2015). However, the hemipenes of Synophis and Emmochliophis (Figure 4, upper) are more similar to one another than they are to those of Diaphorolepis; the similarities include the length of the lobe and the V-shaped anterior edge of capitulum, formed by the capitular groove. See hemipenis of S. lasallei (Nicéforo-Maria, 1950) and S. bicolor Peracca, 1896 in Zaher (1999: 161162), Sánchez-Martínez (2011：152); S. bogerti Torres-Carvajal, Echevarría, Venegas, Chávez and Camper, 2015, S. zamora Torres-Carvajal, Echevarría, Venegas, Chávez and Camper, 2015, and S. insulomontanus Torres-Carvajal, Echevarría, Venegas, Chávez and Camper, 2015 in Torres-Carvajal et al. (2015: 162, 169, 173). Although the hemipenes of both Diaphorolepis and E. miops have a basal pocket, the hemipenis of Diaphorolepis (Remarks) is robust, with short lobes. In addition, the capitular grooves form a round shape; the sulcus spermaticus forks near the base of organ and the calcified spines of the body are larger (Figure 4, lower). These features suggest that Synophis and Emmochliophis are sister taxa, as inferred by Hillis (1990). Further molecular sampling of E. miops is key to our 
understanding of the systematic relationships among the Diaphorolepidini.

Remarks.-The hemipenial description of Diaphorolepis reported herein is based only on the examination of $D$. cf. wagneri (MHNUCHE-Se-0650). The lack of available information on the hemipenis of D. laevis and the brief description for $D$. wagneri provided by Bogert (1964) is inadequate for an appropriate comparison of the hemipenial morphology within the tribe.

The rediscovery of Emmochliophis miops after more than 12 decades is also the first record of the species in Colombia; this extends the distribution of this Critically Endangered species at least $265.5 \mathrm{~km}$ from Parambas, Province of Imbabura, Ecuador, to the La Cueva sector in the Parque Nacional Natural Munchique, municipality of El Tambo, department of Cauca. It seems likely that the species may occur in other localities in the Pacific region of Colombia.

Numerous specimens of Diaphorolepis and Synophis have been collected recently and include five new species (Pyron et al. 2015, 2016, Torres-Carvajal et al. 2015); however, no additional records of Emmochliophis miops have appeared since its original description (Boulenger 1898). Habitat loss in the type locality and surrounding areas plus the apparent sensitivity of the species to changes in humidity reported here and inferred by Cisneros-Heredia and YánezMuñoz (2017) suggest that E. miops may be extirpated in Ecuador.

We agree with the recent proposal concerning Standard Common names for species of Synophis (Pyron et al. 2016) and we extend these criteria to all species of Diaphorolepidini. We support the following names for the remaining species (Spanish names in parentheses): Diaphorolepis laevis = Colombian Shadow Snake (Culebra colombiana de la Sombra); D. wagneri = Wagner's Shadow Snake (Culebra de la Sombra de Wagner); Emmochliophis fugleri = Fugler's Shadow Snake (Culebra de la Sombra de Fugler) and E. miops $=$ Myopic Shadow Snake (Culebra de la Sombra miope).

\section{Acknowledgments}

This research was supported primarily by Parques Nacionales Naturales de Colombia, WCS Colombia, and Fundación Ecohábitats. LEV-P thanks Claudia Acevedo, Liliana Paz and professors Santiago Ayerbe González, María del Pilar Rivas, Jimmy Guerrero, Hernando Vergara and María Cristina Gallego from Universidad del Cauca for their support. Thanks to Ana María Maya, Gustavo Pisso, Gustavo González, and others who assisted with fieldwork. Parques Nacionales Naturales de Colombia is an Environmental Authority that does not require special permits for projects and/or research developed within its own jurisdiction.

\section{References}

Arteaga, A., L. Bustamante, and J. M. Guayasamin. 2013. The Amphibians and Reptiles of Mindo. Quito. Universidad Tecnológica Indoamérica, Serie de Publicaciones Científicas. 257 pp.

Bogert, C. M. 1964. Snakes of the genera Diaphorolepis and Synophis and the colubrid subfamily Xenoderminae. Senckenbergiana Biologica 45: 509-531.

Boulenger, G. A. 1898. An account of the reptiles and batrachians collected by Mr. W. F. H. Rosenberg in Western Ecuador. Proceedings of the Zoological Society of London 1898: 107-126.

Brown, F. M. 1941. A gazetteer of entomological stations in Ecuador. Annals of the Entomological Society of America 34: 809-851.

Cisneros-Heredia, D. F. and M. Yánez-Muñoz. 2017. Emmochliophis miops. The IUCN Red List of Threatened Species 2017. Version 2019-1. Electronic Database accessible at https://www.iucnredlist.org/species/509 51457/50951496. Captured on 13 June 2019.

Dowling, H. G. 1951. A proposed standard system of counting ventrals in snakes. British Journal of Herpetology 1: 97-99.

Dowling, H. G. and J. M. Savage. 1960. A guide to the snake hemipenis: a survey of basic structure and systematic characteristics. Zoologica 45: 17-28.

Fritts, T. H. and H. N. Smith. 1969. A new genus and species of snake from western Ecuador. Transactions of the Kansas Academy of Science 72: 60-66. 
Hillis, D. M. 1990. A new species of xenodontine colubrid snake of the genus Synophis from Ecuador and the phylogeny of the genera Synophis and Emmochliophis. Occasional Papers of the Museum of Natural History University of Kansas 135: 1-9.

IUCN. 2012. IUCN Red List Categories and Criteria: Version 3.1. Second edition. Gland and Cambridge. IUCN. 32 pp.

Lynch, J. D. and W. E. Duellman. 1997. Frogs of the genus Eleutherodactylus in western Ecuador. Systematics, ecology, and biogeography. Special Publication, Natural History Museum, University of Kansas 23: 1-236.

Myers, C. W. and J. E. Cadle. 2003. On the snake hemipenis, with notes on Psomophis and techniques of eversion: a response to Dowling. Herpetological Review 34: 295 302.

Pyron, R. A., J. M. Guayasamin, N. Peñafiel, L. Bustamante, and A. Arteaga. 2015. Systematics of Nothopsini (Serpentes, Dipsadidae), with a new species of Synophis from the Pacific Andean slopes of southwestern Ecuador. ZooKeys 541: 109-147.

Pyron, R. A., A. Arteaga, L. Y. Echevarría, and O. TorresCarvajal. 2016. A revision and key for the tribe Diaphorolepidini (Serpentes: Dipsadidae) and checklist for the genus Synophis. Zootaxa 4171: 293-320.

Sánchez-Martínez, P. M. 2011. Anatomia comparada da tribo Nothopsini (Serpentes, Dipsadidae). Unpublished M.Sc. Dissertation. Universidade de São Paulo, Brazil.
Sheil, C. A. 1998. Emmochliophis miops: redescription of Synophis miops (Boulenger, 1898). Journal of Herpetology 32: 604-607.

Sheil, C. A. and T. Grant. 2001. A new species of colubrid snake (Synophis) from western Colombia. Journal of Herpetology 35: 204-209.

Torres-Carvajal, O., L. Y. Echevarría, P. J. Venegas, G. Chávez, and J. D. Camper. 2015. Description and phylogeny of three new species of Synophis (Colubridae, Dipsadinae) from the tropical Andes in Ecuador and Peru. ZooKeys 546: 153-179.

Uzzell, T. M. 1973. A revision of lizards of the genus Prionodactylus, with a new genus for P. lecostictus and notes on the genus Euspondylus (Sauria: Teiidae). Postilla 159: 1-67.

Zaher, H. 1999. Hemipenial morphology of the South American xenodontine snakes, with a proposal for a monophyletic Xenodontinae and a reappraisal of colubroid hemipenes. Bulletin of the American Museum of Natural History 240: 1-168.

Zaher, H. and A. L. Prudente. 2003. Hemipenes of Siphlophis (Serpentes, Xenodontinae) and techniques of hemipenial preparation in snakes: a response to Dowling. Herpetological Review 34: 302-307.

Editor: Ross D. MacCulloch

\section{Appendix I. Specimens examined.}

Diaphorolepis cf. wagneri: COLOMBIA. CAuCA: municipality of El Tambo, Parque Nacional Natural Munchique, sector La Cueva, 02 ${ }^{\circ} 46^{\prime} 14.6^{\prime \prime}$ N, 76 58'52.4" W, 1090 m a.s.1. (MHNUC-HE-Se-0650).

Emmochliophis miops: COLOMBIA. CAUCA: municipality of El Tambo, Parque Nacional Natural Munchique, sector La Cueva: 0246'13.1" N, 7658'47.7" W, $1142 \mathrm{~m}$ a.s.1. (MHNUC-HE-Se-0657); 0246'13.6" N, 7658'44.5" W, $1188 \mathrm{~m}$ a.s.1. (MHNUC-HE-Se-0658). ECUADOR. ImbabURA: Parambas, 0048'18" N, 78²1'03" W, 780 m a.s.1. (BMNH 1946.1.12.30, holotype). 